


\section{Voorjaarsbemestingsadvies grasland op basis van bodemtemperatuur}

Deskstudie

Luuk Gollenbeek en Idse Hoving

Dit onderzoek is uitgevoerd door Wageningen Livestock Research, in opdracht van ZuivelNL en deels gefinancierd door Topsector Agrifood.

Wageningen Livestock Research

Wageningen, december 2016

Rapport 1004 
Gollenbeek, L.R., Hoving, I.E. 2016. Voorjaarsbemestingsadvies grasland op basis van

bodemtemperatuur; Deskstudie. Wageningen Livestock Research, Rapport 1004.

Samenvatting NL

In het bemestingsadvies voor grasland wordt in het vroege voorjaar het tijdstip voor bemesting met stikstofkunstmest bepaald op basis van Tsom. De Tsom is voor gemiddelde weerjaren een goede benadering, maar is een te grove richtlijn in jaren met afwijkende weersomstandigheden. In het voorliggende rapport staan de resultaten van een deskstudie die uitgevoerd is om inzicht te krijgen in de relatie tussen bodemtemperatuur, het tijdstip van bemesting en gewasgroei afhankelijk van de grondsoort en het type meststof en invloed van overige omstandigheden zoals bodemvocht en neerslagpatroon. Geconcludeerd wordt dat bodemtemperatuur een parameter kan zijn waarmee het bemestingsadvies voor de eerste snede verbeterd kan worden. Om de relatie tussen grasgroei, bodemtemperatuur en bemestingstijdstip voor stikstofkunstmest te bepalen wordt aanbevolen om een veldonderzoek uit te voeren.

\section{Summary UK}

Currently the Tsum is used in order to determine the optimum for applying nitrogen fertilizers to grassland in spring. The Tsum is a parameter based on average meteorological circumstances, and the Tsum is therefore less applicable for deviating weather conditions. In this report the results of a desk study carried out to enhance knowledge about the relationship between soil temperature, time of fertilization and growth of grass depending on soil type and type of fertilizer and other parameters like soil moisture and precipitation are presented. It is concluded that the determination of the optimal moment of early spring fertilizer application might be improved by using soil temperature. Therefore it is advised to investigate the relationship between soil temperature and grass growth and nitrogen fertilizer application during field trails.

Dit rapport is gratis te downloaden op http://dx.doi.org/10.18174/402252 of op www.wur.nl/livestock-research (onder Wageningen Livestock Research publicaties).

\section{(C) 2016 Wageningen Livestock Research}

Postbus 338, 6700 AH Wageningen, T 03174839 53, E info.livestockresearch@wur.nl, www.wur.nl/livestock-research. Wageningen Livestock Research is onderdeel van Wageningen University \& Research.

Wageningen Livestock Research aanvaardt geen aansprakelijkheid voor eventuele schade voortvloeiend uit het gebruik van de resultaten van dit onderzoek of de toepassing van de adviezen.

Alle rechten voorbehouden. Niets uit deze uitgave mag worden vermenigvuldigd en/of openbaar gemaakt worden door middel van druk, fotokopie, microfilm of op welke wijze dan ook zonder voorafgaande toestemming van de uitgever of auteur.

De certificering volgens ISO 9001 door DNV onderstreept ons kwaliteitsniveau. Op als onze onderzoeksopdrachten zijn de Algemene Voorwaarden van de Animal Sciences Group van toepassing. Deze zijn gedeponeerd bij de Arrondissementsrechtbank Zwolle. 



\section{Inhoud}

$\begin{array}{ll}\text { Woord vooraf } & 5\end{array}$

$\begin{array}{ll}\text { Samenvatting } & 7\end{array}$

1

$\begin{array}{ll}\text { Inleiding } & 9\end{array}$

2

$\begin{array}{ll}\text { Huidige systematiek Tsom } & 10\end{array}$

$\begin{array}{lll}2.1 & \text { Totstandkoming van de Tsom } & 10\end{array}$

2.2 Gebruik Tsom in de praktijk 11

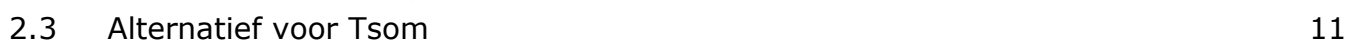

3

$\begin{array}{ll}\text { Grasgroei en bodemtemperatuur } & 13\end{array}$

3.1 Werkwijze deskstudie 13

3.2 Resultaten 13

3.2.1 Relatie grasgroei en bodemtemperatuur 13

3.2.2 Ontwikkeling bodemtemperatuur $\quad 15$

3.2.3 Vuistregels en praktijkervaringen $\quad 17$

4

Discussie

19

5

Conclusie

20

6

Aanbevelingen

21

Literatuur

23 



\section{Woord vooraf}

In het huidige bemestingsadvies wordt het bemestingsmoment voor stikstofkunstmest in het voorjaar gebaseerd op temperatuursom. In de praktijk wordt dit als een grove maat ervaren en is er behoefte aan het nauwkeuriger vaststellen van het tijdstip van bemesting om de grasopbrengst en de nutriëntenbenutting te verhogen.

Door middel van een deskstudie is verkend of met het meten van bodemtemperatuur het bemestingstijdstip daadwerkelijk beter op de actuele groeiomstandigheden in het voorjaar afgestemd kan worden. Het onderzoek is uitgevoerd in opdracht van ZuivelNL onder auspiciën van de Commissie Bemesting Grasland en Voedergewassen.

Het rapport beoogt een onderbouwing te geven voor het toepassen van bodemtemperatuur als parameter in het vaststellen van het optimale bemestingstijdstip voor stikstofkunstmest op gras in het voorjaar.

Dr. ir. B.G. Meerburg

Afdelingshoofd Veehouderij en omgeving, Wageningen Livestock Research 


\section{Samenvatting}

Het huidige bemestingsadvies voor gras in het voorjaar maakt gebruik van de temperatuursom (Tsom) om het optimale tijdstip van bemesting voor kunstmest vast te stellen. In de praktijk wordt de Tsom als een te grove richtlijn ervaren veelal doordat de Tsom eerder wordt bereikt dan dat gras daadwerkelijk gaat groeien, zoals dat in het voorjaar van 2016 het geval was. Er is zodoende behoefte aan een specifiekere maat voor het optimale bemestingstijdstip. In de praktijk wordt reeds geëxperimenteerd met het meten van bodemtemperatuur om de start van de grasgroei te kunnen voorspellen.

In het voorliggende rapport staan de resultaten van een deskstudie die uitgevoerd is om inzicht te krijgen in de relatie tussen bodemtemperatuur, het tijdstip van bemesting en gewasgroei afhankelijk van de grondsoort en het type meststof en invloed van overige omstandigheden zoals vocht en neerslagpatroon. De studie richtte zich alleen op de voorjaarsbemesting van grasland onder Nederlandse omstandigheden. De primaire onderzoeksvraag is of het meten van de actuele bodemtemperatuur een betere basis voor het voorjaarsbemestingsadvies voor grasland dan het toepassen van Tsom.

De Tsom is ontwikkeld op resultaten van vele jaren van onderzoek naar grasgroei (periode 19601983). In deze proeven is op verschillende grondsoorten en tijdstippen voor de eerste snede bemest met stikstofkunstmest, vooral met kalkammonsalpeter. Het tijdstip van bemesten is afhankelijk gesteld van de streefopbrengst van de eerste snede. De optimale Tsom wordt over het algemeen in februari/maart bereikt. De T-som is gemiddeld over de jaren een redelijke schatter voor het gewenste bemestingstijdstip, maar kan in individuele weerjaren behoorlijk afwijken.

Als alternatief voor de Tsom wordt in de praktijk geëxperimenteerd met het meten van bodemtemperatuur op ongeveer $10 \mathrm{~cm}$ diepte. De meetdiepte zal invloed hebben op de voorspelling, enerzijds vanwege het dag-nachtritme dat teruggevonden wordt in de meetresultaten en anderzijds de worteldiepte. Het merendeel van de wortelmassa bevindt zich namelijk in de laag van $0-10 \mathrm{~cm}$. Ook is niet duidelijk of de bodemtemperatuur als enige parameter voldoende is om de start van de grasgroei te voorspellen.

In de onderzoeken die gebruikt zijn voor de ontwikkeling van de Tsom is geen bodemtemperatuur gemeten. Verder werd slechts één onderzoek gevonden waarin de bodemtemperatuur gemeten is in relatie tot grasgroei. Hierin werden lineaire verbanden gevonden tussen bodemtemperatuur op $10 \mathrm{~cm}$ diepte en de groei van stengels en bladeren bij bodemtemperaturen tussen de 3 en $10^{\circ} \mathrm{C}$. De conclusie was echter dat dit verband niet causaal hoeft te zijn aangezien straling en daglengte ook belangrijke factoren zijn. Natte gronden staan bekend als late gronden. Het is zodoende aannemelijk om te veronderstellen dat bodemtemperatuur een belangrijke rol speelt in de start van de groei.

In februari is de kans op een verschil in ontwikkeling van de Tsom en de bodemtemperatuur het grootst. De bodemtemperatuur kan worden berekend op basis van de luchttemperatuur, echter het betreft een empirische relatie die een benadering is van de werkelijkheid. Factoren als neerslag, bedekking bodemoppervlak met sneeuw, dichtheid grasmat, bodemsoort, bodemvochtgehalte en wind worden niet meegenomen. Gepleit wordt daarom om daadwerkelijk de bodemtemperatuur te gaan meten.

De belangrijkste conclusie van de studie is dat bodemtemperatuur een parameter kan zijn waarmee het bemestingsadvies voor de eerste snede verbeterd kan worden. Misschien niet als vervanger van Tsom, maar mogelijk als extra verklarende variabele. Om de relatie tussen grasgroei in het voorjaar, de bodemtemperatuur en het bemestingstijdstip voor stikstofkunstmest te bepalen wordt aanbevolen om een veldonderzoek uit te voeren. 


\section{$1 \quad$ Inleiding}

Voor het optimale tijdstip van de eerste mestgift in het vroege voorjaar op grasland wordt de temperatuursom (Tsom) gebruikt, echter in het streven naar een efficiënter meststoffengebruik wordt de Tsom door de praktijk als een te grove richtlijn ervaren. De Tsom is ontwikkeld op resultaten van vele jaren van onderzoek naar grasgroei (periode 1960-1983). Deze Tsom systematiek werkt goed voor jaren met een gemiddeld weerbeeld. Echter, indien het verloop van het weer afwijkt van gemiddeld dan lopen de Tsom en de ontwikkeling van de bodemtemperatuur en grasgroei uiteen. In 2014 en 2015 was dit het geval; de Tsom was reeds vroeg in het voorjaar bereikt (uitgaande van een Tsom van 250 in de Bilt), maar de bodemtemperatuur was nog onvoldoende voor het starten van de grasgroei (gebaseerd op meetgegevens uit Stienezen et al., 2016). Ook houdt de T-som onvoldoende rekening met verschil in grondsoorten en wordt niet voorzien in een advies voor drijfmest. Er is zodoende een grote behoefte aan een specifiekere maat voor het optimale bemestingstijdstip. Het meten van de bodemtemperatuur zegt mogelijk meer over de staat 'van de bodem' in relatie tot de activiteit van graswortels en bodemleven. Tegenwoordig zijn bodemthermometers en bodemsensoren beschikbaar om direct de bodemtemperatuur te meten. De sensoren kunnen zelfs op afstand uitgelezen worden. Daarom wordt het meten van de daadwerkelijke bodemtemperatuur als een kans gezien om het advies omtrent het optimale tijdstip voor bemesting in het voorjaar te verfijnen.

$\mathrm{Er}$ is een deskstudie uitgevoerd met als doel om inzicht te geven in de relatie tussen bodemtemperatuur, het tijdstip van bemesting en gewasgroei afhankelijk van de grondsoort en het type meststof en invloed van overige omstandigheden zoals vocht en neerslagpatroon. Belangrijk zijn daarbij de diepte waarop de bodemtemperatuur gemeten wordt, hoe meet je bodemtemperatuur en hoe groot is de spreiding in typen voorjaren en wat is het effect op stikstofbenutting. Gekeken wordt of op basis van bestaande data hiervoor een goede schatting gemaakt kan worden. Uiteindelijk moet onderbouwd worden waarom het meten van bodemtemperatuur een betere basis geeft voor het bemestingsadvies dan de T-som en welke omstandigheden daarbij ook betrokken moeten worden. De studie richtte zich alleen op de voorjaarsbemesting van grasland onder Nederlandse omstandigheden.

De volgende onderzoeksvragen zijn gesteld:

1) Geeft het meten van de actuele bodemtemperatuur een betere basis voor het voorjaarsbemestingsadvies voor grasland dan het toepassen van Tsom?

2) Welke overige factoren kunnen een advies op basis van bodemtemperatuur beïnvloeden of zelfs overrulen?

3) Is bemestingsadvies op basis van bodemtemperatuur haalbaar, en welk vervolgonderzoek is er nodig om tot een concreet advies te komen? 


\section{Huidige systematiek Tsom}

\subsection{Totstandkoming van de Tsom}

De Tsom is de optelling van de gemiddelde dagelijkse etmaal temperaturen boven nul vanaf 1 januari. De Tsom wordt gebruikt om het gewenste tijdstip te bepalen voor de eerste stikstofkunstmestgift in het vroege voorjaar (Commissie Bemesting Grasland en Voedergewassen, 2012).

De T-som is gebaseerd op veldproeven die tussen 1960 en 1983 zijn uitgevoerd (Bussink, 2006). In deze proeven is op verschillende grondsoorten en tijdstippen voor de eerste snede bemest (bemesting vooral met kalkammonsalpeter, KAS). De analyse van de proefresultaten van 1960-1983 laat zien dat het tijdstip van bemesten afhankelijk is van de streefopbrengst van de eerste snede. Dit is schematisch weergegeven in Figuur 2.1. Vroeg strooien bevordert de grasgroei, echter het risico op stikstofverliezen is groter dan wanneer later gestrooid wordt. Hierdoor is de dagelijkse grasgroei minder dan bij later gegeven stikstof. Een weidesnede van $1500 \mathrm{~kg}$ ds ha-1 wordt nog wel eerder gerealiseerd maar, een maaisnede van $3000 \mathrm{~kg}$ ds ha-1 wordt later gerealiseerd. Gemiddeld varieert het optimale strooitijdstip voor een weidesnede tussen T-som $175-250^{\circ} \mathrm{C}$. Voor een maaisnede varieert het optimum tussen T-som $250-340^{\circ} \mathrm{C}$. Daarbij kunnen er verschillen zijn tussen weerjaren en het optimale strooitijdstip verschilt per grondsoort. De optimale T-som tussen grondsoorten kan ongeveer 50 eenheden verschillen. De optimale Tsom wordt over het algemeen in februari/maart bereikt.

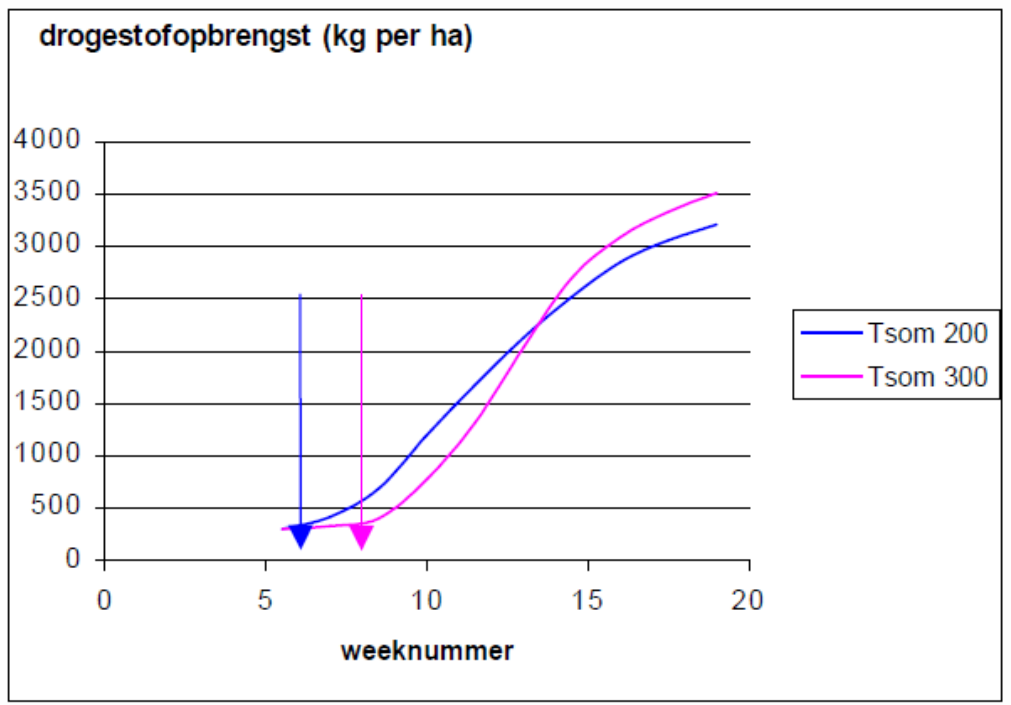

Figuur 2.1 Het theoretische effect van het bemestingstijdstip op het opbrengstverloop, schematisch weergegeven (Bussink, 2006).

Bij het bemestingsadvies op basis van de Tsom worden in de huidige systematiek ook de regio en grondsoort meegenomen. In 1999 (Bussink, 1999) is op basis van de onderzoeksgegevens uit 19601983 een nadere studie uitgevoerd om een verfijnde Tsom op te stellen. Geconcludeerd werd dat bij kleigronden (anders dan rivierklei en zand) de optimale Tsom voor sturing op efficiënt $\mathrm{N}$ gebruik lager ligt dan bij veen, rivierklei en löss. Waarschijnlijk is dit te wijten aan de geringe $\mathrm{N}$ verliezen op kleigronden.

Het effect van eerder of later bemesten dan het optimale tijdstip op de opbrengst wordt kleiner indien de zwaarte van de gewenste snede toeneemt (dus bij een weidesnede is het optimale bemestingstijdstip crucialer dan bij een maaisnede). Indien gestuurd wordt op een zo efficiënt mogelijke N-benutting dan zal de Tsom met 90 graden verhoogd moeten worden. De N-efficiëntie kan hiermee 4 procent verhoogd worden terwijl de drogestof productie $100 \mathrm{~kg} / \mathrm{ha}$ voor de eerste snede daalt. (Bussink, 1999). 
NMI heeft geconcludeerd dat zowel een afname in droge stof productie als in ruw eiwit wordt veroorzaakt door regenval of een vorstperiode die plaatsvindt kort nadat kunstmest gestrooid is (Bussink 2000, 1999). Vorst leidt tot een verlies van 200-400 kg droge stof per hectare op jaarbasis en regen tot $400 \mathrm{~kg}$ droge stof per hectare op jaarbasis, tevens treedt nutriëntenverlies op (Bussink, 2016).

De Tsom is ontwikkeld om een juiste afweging te maken tussen een goede efficiency door op tijd te strooien en het voorkomen van verliezen door niet te vroeg te strooien. De vorm van kunstmest is een belangrijk gegeven hierin. Het Tsom advies is ontwikkeld voor de meest gebruikte kunstmeststof kalkammonsalpeter (KAS), een 50-50\% mengsel van nitraat en ammonium. Vooral nitraat is uitspoelingsgevoelig en bij te vroeg strooien kan een groot deel verloren gaan.

Tegenwoordig worden er echter steeds meer andere vormen van kunstmest gebruikt. Het is daarom ook de vraag of daar hetzelfde traject van optimale Tsom voor geldt.

\subsection{Gebruik Tsom in de praktijk}

In de praktijk wordt de Tsom door melkveehouders en loonwerkers gebruikt om te bepalen wanneer ze de eerste mestgift geven. Hierbij worden ook de weersvoorspelling en praktische zaken als bereidbaarheid perceel, beschikbaar materieel en beschikbare arbeid meegenomen.

De actuele Tsom kan op verschillende websites gevonden worden. Het NMI houdt tegenwoordig in het bemestingsadvies op basis van de Tsom ook rekening met onder andere de 10-daagse weersvoorspelling en het feit of gestuurd moet worden op drogestof opbrengst of ruw eiwit opbrengst (Re-gras).

De Tsom is gemiddeld over de jaren een redelijke schatter voor het gewenste bemestings-tijdstip van de eerste snede voor gras, maar geeft voor de actuele situatie in het voorjaar een afwijking. Er is zodoende behoefte aan een specifiekere maat voor het optimale bemestingstijdstip.

De Tsom is ontwikkeld voor het geven van de eerste stikstofkunstmestgift en niet voor het toedienen van drijfmest (Commissie Bemesting Grasland en Voedergewassen, 2012). Voor drijfmest wordt volgens het advies het wettelijke toegestane uitrijtijdstip aangehouden (15 februari), mits de grond niet meer bevroren of met sneeuw bedekt is en de draagkracht van de grond berijding toelaat. Aangezien door de huidige gebruiksnormen het toepassen van drijfmest steeds meer op de voorgrond gekomen is, zijn nadere criteria voor het uitrijden van drijfmest gewenst. Veelal wordt reeds met het uitrijden van de eerste drijfmestgift gewacht tot begin maart, wanneer de risico's op vorst en neerslagoverschot kleiner zijn, echter het ontbreekt aan duidelijke criteria voor het optimale bemestingstijdstip.

\subsection{Alternatief voor Tsom}

Als alternatief voor de Tsom wordt in de praktijk geëxperimenteerd met het meten van bodemtemperatuur. Agrifirm stelt dat grasgroei start bij een bodemtemperatuur van 5 à $8{ }^{\circ} \mathrm{C}$ (Agrifirm, 2014). Hierbij wordt een meetdiepte aangehouden van $10 \mathrm{~cm}$. Uit een eerste verkenning bij coöperatie KTC Zegveld blijkt dat bij het meten op een diepte van $20 \mathrm{~cm}$ de variatie in luchttemperatuur meer wordt gedempt en het verloop van de bodemtemperatuur aanmerkelijk stabieler is. Op een diepte van $10 \mathrm{~cm}-\mathrm{mv}$ wordt nog sterk het dag nachtritme waargenomen. Frame and Laidlaw (1992) vermelden dat in Ierland, voor de start van grasgroei uitgegaan wordt van een bodemtemperatuur van $6^{\circ} \mathrm{C}$ op 5 achtereenvolgende dagen. Daarbij wordt de bodemtemperatuur op een diepte van $10 \mathrm{~cm}$ gemeten. Een verdere nuancering van het meten van bodemtemperatuur is gewenst. 
Het is niet duidelijk of de bodemtemperatuur als enige parameter voldoende is om de start van de grasgroei te voorspellen. Uitgezocht moet worden of ook andere parameters als bijvoorbeeld luchttemperatuur bodemsoort en bodemvocht meegenomen moeten worden. 


\section{Grasgroei en bodemtemperatuur}

\subsection{Werkwijze deskstudie}

In het voorliggende rapport is een uiteenzetting gegeven van hetgeen bekend is over de start van de groei van gras in relatie tot de bodemtemperatuur en andere factoren. Hiertoe is literatuur onderzocht (WUR Global Search, google.nl en scholar.google.nl) en zijn de experts Wim Bussink (NMI), Jantine van Middelkoop en Gertjan Holshof (Wageningen Livestock Research) en Frank Lenssinck (Veenweide Innovatie Centrum) geraadpleegd.

In de eerste plaats is geïnventariseerd wat vanuit het praktijkonderzoek in Nederland bekend is rondom T-som en de relatie tussen de start van grasgroei en bodemtemperatuur. In de tweede plaats is onderzocht wat hier vanuit de wetenschappelijke literatuur bekend is.

\subsection{Resultaten}

\subsubsection{Relatie grasgroei en bodemtemperatuur}

\section{Bodemtemperatuur en grasgroei}

Van de onderzoeken naar grasgroei (periode 1960-1983) op basis waarvan de Tsom is vastgesteld zijn twee rapportages gevonden (Schothorst, 1980 en De Gooijer, 1968). In beide rapportages wordt geen melding gemaakt van metingen van de bodemtemperatuur. Ook staat in de betreffende dataset uit de periode 1960 tot 1983 geen bodemtemperatuur als meetwaarde (persoonlijke informatie Gertjan Holshof). In Schothorst (1968) wordt op basis van een analyse van de dataset geconcludeerd dat de grasgroei op slecht ontwaterde bodems later op gang komt (gemiddeld 4 dagen) dan op de goed ontwaterde bodems. Een verklaring voor dit verschil is niet gegeven. Een zeer waarschijnlijke verklaring is dat relatief vochtige bodems minder snel opwarmen dan relatief droge bodems door de hoge warmtecapaciteit van water.

De Gooijer (1968) concludeert dat in een normaal verlopend voorjaar een gemiddelde Tsom van $240{ }^{\circ} \mathrm{C}$ als start van de grasgroei aangehouden kan worden. Wel wordt hierbij opgemerkt dat de spreiding groot is, wat mogelijk wordt veroorzaakt door de grote verschillen in de proefvelden. Baker and Younger 1986, toonden een relatie aan tussen de temperatuur van het bodemoppervlak (dus niet in de bodem) en de grasgroei. De grasgroei was niet volledig te relateren aan het verloop van de oppervlaktetemperatuur. Ook in dit onderzoek was de start van de grasgroei op de slecht ontwaterde velden later dan op de goed ontwaterde velden.

Bij de start van grasgroei worden vooral de reserves (koolhydraten) aangesproken die aanwezig zijn in de stoppels en nog aanwezige bladeren en de wortels (Lambert et al., 1999). Dit proces wordt door temperatuur (geen onderscheid in bodem- of luchttemperatuur) gedreven (uit Lambert et al., 1999 gebaseerd op Lemaire, Salette, 1981 and Thomas, Norris, 1977). Indien er voldoende bladoppervlak is en voldoende straling van de zon dan schakelt het mechanisme over op koolhydraten die door middel van fotosynthese worden geproduceerd. Na het oogsten van gras (maaien of weiden) zal wederom de groei op gang komen door aanspraak te maken op de aanwezige reserves. In het onderzoek van Lambert et al. is grasgroei gerelateerd aan de Tsom. Ook in dit onderzoek is de bodemtemperatuur niet gemeten. In een veldonderzoek naar de groei van gras in Wales (heuvels en laagland) van Thomas en Norris (1977) is de bodemtemperatuur wel gemeten. Hierin werden lineaire verbanden gevonden tussen bodemtemperatuur op $10 \mathrm{~cm}-\mathrm{mv}$ en de groei van stengels en bladeren, bij bodemtemperaturen tussen de 3 en $10^{\circ} \mathrm{C}$. Geconcludeerd wordt dat dit verband niet causaal hoeft te zijn aangezien straling en daglengte ook belangrijke factoren kunnen zijn (Thomas en Norris, 1977). De grasgroei wordt volgens Barthel (2014) aangestuurd vanuit het ondergrondse en het bovengrondse deel van de plant. De verdeling van koolstof in het gras is volgens deze literatuurbron een dynamisch proces waarbij temperatuur een effect heeft op de verdeling van koolstof tussen het bovengrondse en het ondergrondse deel. Bij een temperatuurval (lucht) van $25{ }^{\circ} \mathrm{C}$ naar $10{ }^{\circ} \mathrm{C}$ werd een lagere transportsnelheid van koolstof tussen ondergronds en bovengronds deel van het gras gemeten. 
Het betreffende gras investeerde tevens relatief meer koolstof in het ondergrondse deel bij een lage temperatuur. Er werden geen onderzoeken gevonden waarin de sturing van fysiologische processen in gras gerelateerd zijn aan bodemtemperatuur en luchttemperatuur.

Voor de groei is ook de temperatuur in relatie tot de straling van belang. In het voorjaar is de temperatuur laag en de straling relatief hoog, in het najaar is juist de temperatuur hoog maar de straling laag. Dus in het voorjaar zal temperatuur limiterend zijn boven straling (Vischer 2010).

Tabel 3.1 Gemiddelde maandelijkse dagtemperatuur in ${ }^{\circ} \mathrm{C}$ en globale stralingssom in $\mathrm{J} / \mathrm{cm}^{2}$ per dag in Nederland, periode 1971-2000 (bron KNMI, uit Vischer 2010).

\begin{tabular}{lcccccccccccc} 
Maand & Jan & Feb & Mrt & April & Mei & Juni & Juli & Aug & Sept & Okt & Nov & Dec \\
Temperatuur & 2,8 & 2,9 & 5,6 & 8,0 & 12,3 & 14,9 & 17,1 & 17,2 & 14,4 & 10,6 & 6,5 & 4,1 \\
\hline Stralingssom & 233 & 482 & 827 & 1345 & 1748 & 1808 & 1764 & 1541 & 1025 & 603 & 291 & 173 \\
\hline
\end{tabular}

Mogelijk wordt de start van de grasgroei tevens beïnvloed door de omstandigheden tijdens de aanloop naar de juiste bodemtemperatuur (of Tsom). Het bodemleven moet op gang komen ten behoeve van de mineralisatie. Een zeer snelle opwarming is dan mogelijk minder effectief dan een langzaam opbouwende bodemtemperatuur (Persoonlijke mededeling Jantine van Middelkoop).

\section{Bodemtemperatuur en beschikbaarheid van nutriënten (mineralisatie)}

Daarnaast speelt de mineralisatie van organische stof in de bodem een rol bij de groei van gras. Door mineralisatie komen nutriënten beschikbaar. In eerste instantie zal bij opwarming van de bodem het bodemleven (micro-organismen en macrofauna) deze nutriënten opnemen waardoor deze nutriënten niet direct beschikbaar komen voor de planten. Echter indien de populatie micro-organismen niet meer groeit of daalt zullen deze nutriënten beschikbaar komen voor de plant. Mineralisatie is sterk afhankelijk van micro-organismen. Voor micro-organismen zijn bodemtemperatuur, -vocht en -pH van belang (Whitehead 2000).

In Ros et al. (2010) wordt geconcludeerd dat mineralisatie voornamelijk gerelateerd is aan bodemtemperatuur en vochtgehalte. Voor wat betreft de absolute hoeveelheid mineralisatie die optreedt in verschillende bodems zijn de parameters die met organische stof te maken hebben het meest leidend. De kwantiteit en kwaliteit van de organische stof zijn bepalend voor de hoeveelheid nutriënten die kunnen vrijkomen.

De relatie tussen bodemtemperatuur en mineralisatie wordt volgens Kirschbaum met de volgende formule beschreven: $\mathrm{k}=\mathrm{e}^{\{3,36(\mathrm{Te}-40 / \mathrm{Te}+31,79)+1,297\}}$ met: $\mathrm{k}$ correctiefactor (uitgaande van referentietemperatuur $20^{\circ} \mathrm{C}$ ) en Te de temperatuur (Ros et al., 2010). Het betreft de theoretische benadering van de mineralisatie snelheid. Te zien is dat mineralisatie bij lage bodemtemperaturen $\left(<5{ }^{\circ} \mathrm{C}\right)$ nauwelijks optreedt. Ook zullen bij dergelijke bodemtemperaturen de beschikbare nutriënten

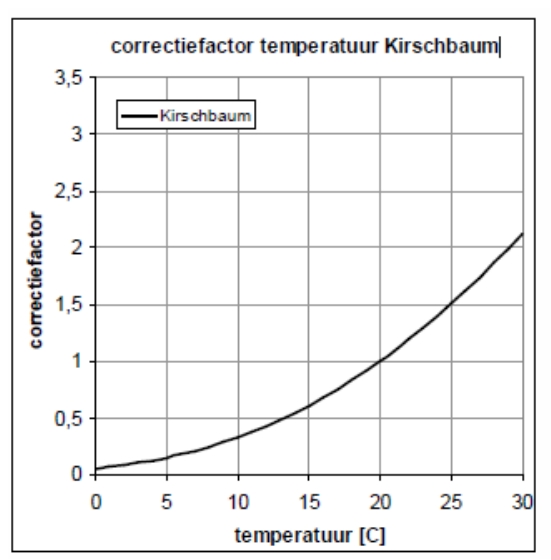
gebruikt worden voor de opbouw van microbiologische massa (Whitehead 2000). Als we er vanuit gaan dat de start van de groei om en nabij de $5-8{ }^{\circ} \mathrm{C}$ ligt, zullen de beschikbare hoeveelheden nutriënten laag zijn bij de start. Verwacht wordt dat bij de start van de grasgroei de nutriënten opname ook laag zal zijn. Er zijn geen gegevens in de literatuur gevonden waaruit blijkt hoe de verhouding gewasopname en mineralisatie snelheid bij de start van de grasgroei is.

Figuur 3.1 Correctiefactor mineralisatie volgens Kirschbaum. ( $20{ }^{\circ} \mathrm{C}$ is referentie temperatuur). 
Op de Marke is onderzoek uitgevoerd naar de mineralisatie die optreedt bij gras en mais (Verloop, 2013). In figuur 3.2 is de gemiddelde mineralisatie per maand weergegeven. In deze studie werd geen duidelijke relatie gevonden tussen mineralisatie en de Tsom. De relatie tussen bodemtemperatuur en mineralisatie is niet onderzocht. In januari en februari is de mineralisatie nog minimaal. In maart en april stijgt de mineralisatie sterk. Deze grafiek laat niet zien hoeveel van de gemineraliseerde stikstof opgenomen wordt door de plant.

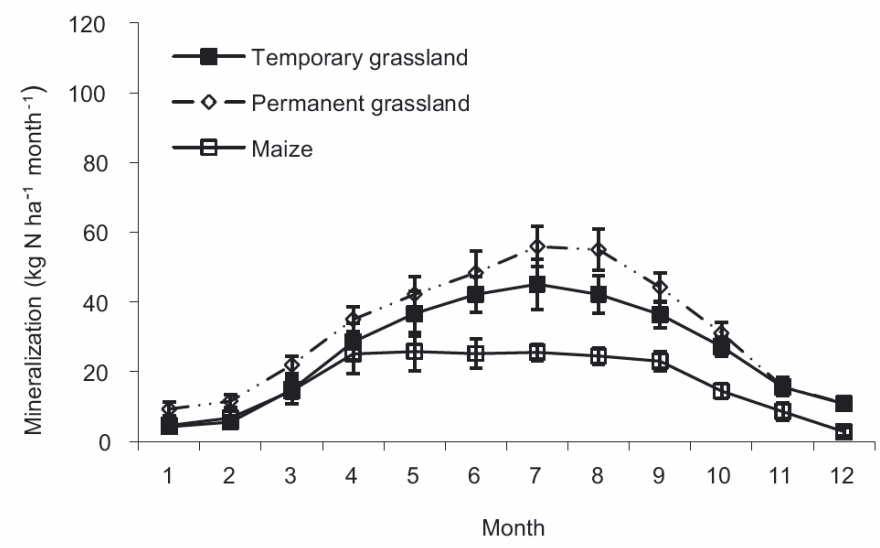

Figuur 3.2 Gemiddelde N-mineralisatie per maand (periode 1993-2005) (Verloop 2013).

\subsubsection{Ontwikkeling bodemtemperatuur}

Bodemtemperatuur is een belangrijke factor voor de groei van planten. Het opwarmen van een bodem is afhankelijk van het vochtgehalte, de structuur en de samenstelling van de bodem (Locher en de Bakker, 1990). De bodem absorbeert stralingsenergie van de zon. Door de veranderende stand van de zon overdag en door de afwisseling van dag en nacht varieert de geabsorbeerde hoeveelheid stralingsenergie. Daardoor varieert ook de bodemtemperatuur aan het oppervlak. Opwarming in de bovengrond wordt door warmtegeleiding doorgegeven aan diepere lagen in de bodem. Omdat warmtegeleiding tijd vraagt, treden de temperatuurswisselingen met de diepte steeds sterker vertraagd op vergeleken met die aan het maaiveld (dempingsdiepte). De dagelijkse temperatuurvariatie neemt niet verder toe dan ongeveer $50 \mathrm{~cm}$ beneden maaiveld. $\mathrm{Bij}$ bedekte grond is het de graslaag die de inkomende straling ontvangt en omzet in warmte en uitwisselt met de onderliggende bodemlaag en de luchtlaag erboven. De bodem wordt in dit geval indirect opgewarmd. De vegetatie werkt zo als een isolatielaag, waardoor de temperatuurschommelingen in de bodem onder gras ook minder sterk zijn dan in onbedekte grond of in de lucht erboven (Ros et al. 2010). De openheid van de zode kan zodoende invloed hebben op de ontwikkeling van de bodemtemperatuur.

Uit een analyse van Jacobs et al. (2011) van de bodemtemperatuur onder grasland in de periode 1987 tot en met 2010 bleek dat de gemiddelde jaarlijkse bodemtemperatuur in 23 jaar met $1{ }^{\circ} \mathrm{C}$ is gestegen en dat de maandelijkse variatie in bodemtemperatuur (ook voor luchttemperatuur) in februari het sterkst is. Het weer in februari verloopt het ene jaar relatief koud en het andere jaar relatief warm. Ook sneeuwval zorgt voor variatie in bodemtemperaturen. De resultaten van deze studie geven aan dat in februari de kans op een verschil in ontwikkeling van de Tsom en de bodemtemperatuur het grootst is. Omdat bij de Tsom gestart wordt met meten vanaf januari kan dan ook een groot verschil ontstaan tussen het verloop van de Tsom en het verloop van de bodemtemperatuur. Dit pleit voor het toepassen van de directere maat bodemtemperatuur.

De warmtestroming wordt bepaald door twee onafhankelijke thermische parameters te weten de warmtegeleidingscoëfficiënt $(\lambda)$ en de warmtecapaciteit $(C)$. Het warmtegeleidingsvermogen wordt in hoofdzaak bepaald door het totale contactoppervlak tussen de bodembestanddelen en is daardoor sterk afhankelijk van het vochtgehalte en de dichtheid van de bodem. Het warmtegeleidingsvermogen is minimaal in droge grond en maximaal in volledig met water verzadigde grond. 
De warmtecapaciteit van grond is opgebouwd uit de warmtecapaciteiten van organische stof, minerale delen en bodemvocht. De warmtecapaciteit van bodemlucht is verwaarloosbaar klein. Het vochtgehalte heeft grote invloed op de warmtecapaciteit van de grond. Het opwarmen van een natte grond vereist meer energie dan van een droge grond en zal over het algemeen langer duren. Vooral het vochtgehalte en het organische stofgehalte hebben grote invloed op de thermische eigenschappen van een grond (Locher en de Bakker, 1990). De warmte balans van de bodem kan volgens als volgt worden berekend (Moene en Van Dam 2010): Shs = Q* - Shv - Sha - LvE - Gz - H

Met:

- Shs, $\Delta$ warmteopslag

- $Q^{*}$, Netto straling

- Shv, Sha, $\Delta$ warmteopslag vegetatie en lucht

- LvE, Evapotranspiratie

- Gz, warmteflux van en naar diepere bodemlagen.

- $\mathrm{H}$, warmteflux wind

Om de bodemtemperatuur te berekenen op basis van de luchttemperatuur is een empirische benadering mogelijk vastgesteld door het KNMI met de formule (Ros et al., 2010):

$\mathrm{T}_{\text {bodem-5cm }}=1,12 * \mathrm{~T}_{\text {lucht } 150}+0,3$

Indien ook rekening gehouden wordt met de luchttemperaturen in voorgaande periode, dan is de empirische formule als volgt:

$\mathrm{T}_{\text {bodem } 5 \mathrm{~cm}}=0,2 \mathrm{~T}_{\text {dagi }}+0,2 \mathrm{~T}_{\text {dag(i-1) }}+0,5 \mathrm{~T}_{\text {decade( }(\mathrm{i}-2 \text { tot } \mathrm{i}-11)}+0,2 \mathrm{~T}_{\text {decade }(\mathrm{i}-12 \text { tot } \mathrm{i} 21)}$

Opgesteld door Kirschbaum in 2009, aangepast naar de Nederlandse situatie door Ros et al (2010).

Er zijn dus mogelijkheden om bij benadering de bodemtemperatuur af te leiden van de luchttemperatuur. Echter het empirische karakter van deze formules kan leiden tot afwijkingen in de praktijk. Factoren als neerslag, bedekking bodemoppervlak met sneeuw, dichtheid grasmat, bodemsoort, bodemvochtgehalte en wind worden niet meegenomen. Gepleit wordt daarom om daadwerkelijk de bodemtemperatuur te gaan meten.

Voor het meten van bodemtemperatuur is het belangrijk om rekening te houden met het tijdstip en de diepte in de bodem. Met een continue meting van de temperatuur kan het temperatuursverloop van een bodem per diepte in beeld gebracht worden. Figuur 3.3 laat de resultaten van het temperatuursverloop in een veenbodem zien op twee diepten gemeten bij Coöperatie KTC-Zegveld (http://zegveld.acaciadata.com/).

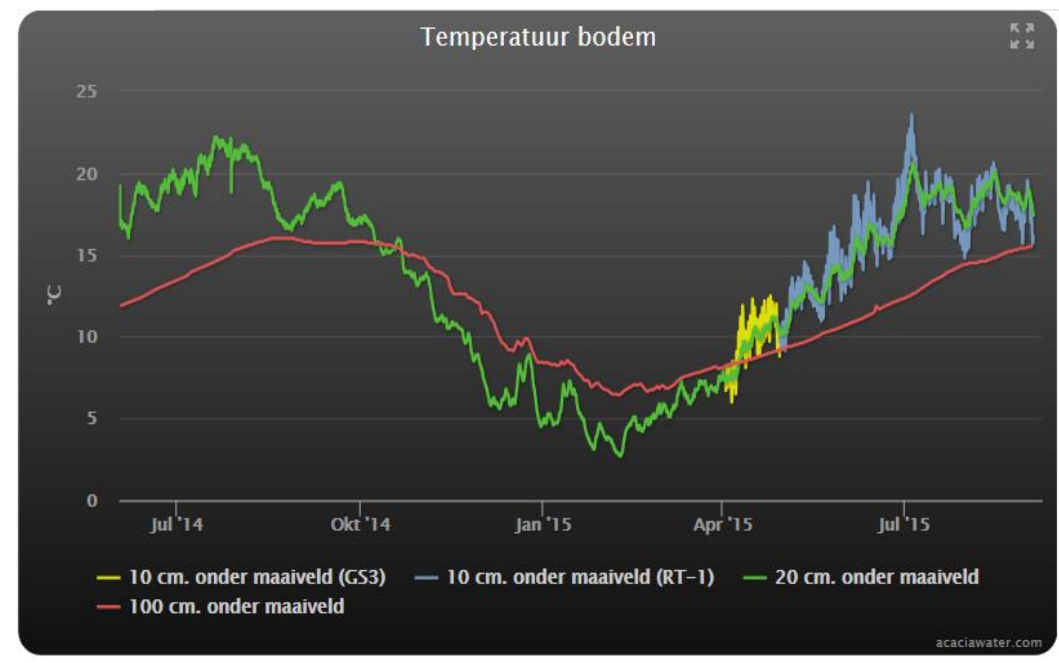

Figuur 3.3 Temperatuursverloop gemeten 10, 20 en $100 \mathrm{~cm}$ beneden maaiveld (http://zegveld.acaciadata.com/). 
Het cyclische temperatuursverloop gedurende het jaar is in figuur 3.3 te zien. De metingen op $100 \mathrm{~cm}$ beneden maaiveld vertonen een fase verschil (ijlen na) met de metingen op 10 en $20 \mathrm{~cm}$ beneden maaiveld door demping van de warmtegeleiding. De metingen op $20 \mathrm{~cm}$ laten een aanmerkelijk kleinere variatie in bodemtemperatuur zien dan de metingen op $10 \mathrm{~cm}$ beneden maaiveld door uitdoving van de invloed van het dag-nachtritme op de bodemtemperatuur.

Een diepere en intensievere beworteling draagt bij aan een betere nutriëntenbenutting. Naast beperkende factoren vanuit de bodemgesteldheid zijn management maatregelen mogelijk om een diepere en intensievere beworteling te bewerkstelligen (Deru et al 2010). Een intensievere en diepere beworteling zorgt voor een veerkrachtiger gewas, onder andere door minder risico's op droogte en nutriënt tekorten. Tevens wordt de concurrentiepositie beter (Ennik 1981). Bij gras is ongeveer $80 \%$ van de wortelbiomassa aanwezig in de bovenste $30 \mathrm{~cm}$ van het bodemprofiel. In deze studies is geen onderzoek gedaan naar de start van de grasgroei in relatie tot beworteling. Nog niet bepaald is of de bewortelingsdiepte van invloed is op de start van de grasgroei.

\subsubsection{Vuistregels en praktijkervaringen}

Agrifirm stelt dat grasgroei start bij een bodemtemperatuur van 5 à $8{ }^{\circ} \mathrm{C}$ met een optimum van $15^{\circ} \mathrm{C}$ (Agrifirm, 2014). Boven de $25^{\circ} \mathrm{C}$ zal de grasgroei stoppen. Hierbij wordt een meetdiepte aangehouden van $10 \mathrm{~cm}$. Frame and Laidlaw (1992) vermelden dat in Ierland, voor de start van grasgroei uitgegaan wordt van een bodemtemperatuur van $6^{\circ} \mathrm{C}$ op 5 achtereenvolgende dagen. Daarbij wordt de bodemtemperatuur op een diepte van $10 \mathrm{~cm}$ gemeten. Overeenkomstige adviezen zijn op internet aangetroffen bij adviesbureaus in binnen- en buitenland voor de agrarische sector.

Uit een eerste verkenning op coöperatie KTC Zegveld blijkt dat bij het meten op een diepte van $20 \mathrm{~cm}$ de variatie in luchttemperatuur meer wordt gedempt en het verloop van de bodemtemperatuur aanmerkelijk stabieler is. Hiermee kan mogelijk een nog betere inschatting gedaan worden van de start van de grasgroei. Echter bij dieper meten zal rekening gehouden moeten worden met de bewortelingsdiepte en -intensiteit (zie ook paragraaf 3.2.2 conditie gras). In de projecten Amazing Grazing en Dynamisch beweiden zijn door een aantal veehouders verspreid over Nederland de bodemtemperatuur en grasgroei gemeten (zie figuren 3.4 en 3.5). Op basis van de gemiddelden startte de grasgroei in 2014 bij een bodemtemperatuur van circa $8{ }^{\circ} \mathrm{C}$ halverwege maart (Remmelink et al., 2015) en in 2015 ook bij circa $8{ }^{\circ} \mathrm{C}$ begin april. Terwijl een Tsom van $250{ }^{\circ} \mathrm{C}$ in 2014 al half februari en in 2015 begin maart werden bereikt, vastgesteld op basis van gegevens van het KNMI meetstation de Bilt).

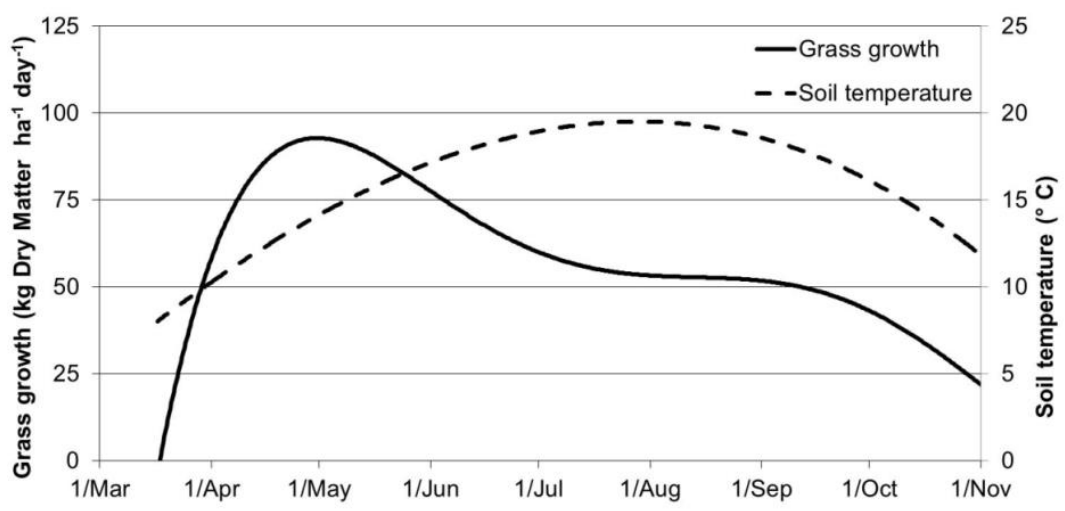

Figuur 3.4 Gemiddelde grasgroei- en bodemtemperatuurcurve 2014 voor Nederland (Stienezen et al., 2016). 


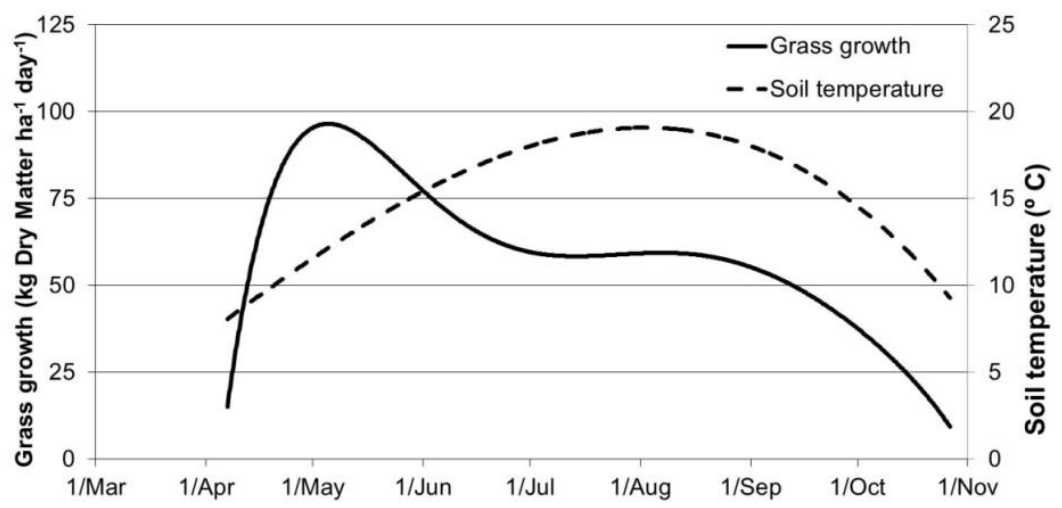

Figur 3.5 Gemiddelde grasgroei- en bodemtemperatuurcurve 2015 voor Nederland (Stienezen et al., 2016). 


\section{Discussie}

De onderzoeken (periode 1960-1983) waar de Tsom op gebaseerd zijn, waren ingestoken op het behalen van de hoogste opbrengst van de eerste snede in relatie tot het tijdstip van bemesten met KAS. Het onderzoek gaat niet in op de processen in bodem en plant die belangrijk zijn voor de groei van het gras. De bodemtemperatuur is niet gemeten in deze onderzoeken. De Tsom is de uitkomst van deze onderzoeken en moet gezien worden als een gemiddelde advies over de betreffende jaren. In de studies is aangegeven dat voor enkele jaren (met afwijkende weerbeelden) minder goede resultaten werden geboekt met de Tsom. Het advies rondom de Tsom is in latere studies meermaals aangepast, om bijvoorbeeld te compenseren voor grondsoort, regio of gewenste product (weidesnede, maaisnede) en sturen op stikstof efficiëntie of op drogestof productie. Tevens wordt de 10 daagse weersvoorspelling meegenomen in het bemestingsadvies. Al deze aanpassingen zijn gedaan op basis van nieuwe gegevensanalyses op de dataset 1960-1983 (Bussink 1999, 2006 en 2016).

De voorspelling van het actuele moment waarop gras gaat groeien op basis van luchttemperatuur blijft echter onnauwkeurig. In Schothorst (1980) en De Gooijer, (1968) werd gesteld dat op natte gronden de grasgroei later op gang kwam. Ook in de praktijk staan natte gronden bekend als late gronden. Het is zodoende aannemelijk om te veronderstellen dat bodemtemperatuur een belangrijke rol speelt in de start van de groei. Natte gronden warmen minder snel op door de hoge warmtecapaciteit van water. De grondsoort (vochthoudend vermogen van de grond) en het actuele vochtgehalte in de bovengrond zijn zodoende belangrijke factoren voor de start van de groei. Met het meten van bodemtemperatuur worden deze factoren teruggebracht tot een verklarende parameter in de voorspelling van start van de groei.

De deskstudie was gericht op het vinden van een relatie tussen de actuele bodemtemperatuur en grasgroei in het voorjaar, hoe dit zich verhoudt tot Tsom en welke factoren hier verder op van invloed zijn. De omvang van de deskstudie was te beperkt om de fysiologische achtergrond van het effect van temperatuur op de start van de groei te kunnen achterhalen. In het algemeen is bekend dat voor de fotosynthese van planten water, koolzuurgas en licht nodig is. Zowel de koolzuurgasopname via de huidmondjes als de wateropname via de wortels zijn mogelijk temperatuur gestuurde processen. De beschikbaarheid van nutriënten door mineralisatie is ook een temperatuur gestuurd proces en mogelijk dat hierdoor een interactie-effect op de groei optreedt.

De verwachting is dat het meten van de actuele bodemtemperatuur de voorspelling van de start van groei in het voorjaar verbetert. Misschien niet als vervanger van Tsom, maar mogelijk als extra verklarende variabele. De meetdiepte zal invloed hebben op de voorspelling, enerzijds vanwege het dag-nachtritme dat teruggevonden wordt in de meetresultaten en anderzijds anderzijds vanwege de dikte van de wortelzone, daar waar de interactie met de plant optreedt.

In plaats van het meten van de bodemtemperatuur zou deze ook berekend kunnen worden op basis van de luchttemperatuur. Echter in de empirisch vastgestelde formules zoals voorgesteld bij Ros et al 2010 wordt een generieke bodemtemperatuur bepaald, zonder onderscheid te maken in bodemspecifieke en locatiespecifieke omstandigheden.

Bij het vaststellen van het optimale moment van bemesten moeten ook het gewenste opbrengststadium, de weersvoorspelling en de toe te dienen (kunst)mestsoort worden meegewogen. Voor het toepassen van drijfmest is het advies om zo vroeg mogelijk te bemesten. Er is zijn geen onderzoeken aangetroffen die dit advies onderbouwen of een relatie geven met bodemtemperatuur. 


\section{$5 \quad$ Conclusie}

De conclusies van de studie zijn als volgt:

- In de onderzoeken die gebruikt zijn voor de ontwikkeling van de Tsom is geen bodemtemperatuur gemeten;

- Er werd slechts één onderzoek gevonden waarin de bodemtemperatuur gemeten is in relatie tot grasgroei. Hierin werd een lineair verband gevonden tussen bodemtemperatuur en bladgroei. Daarbij was de conclusie dat dit verband niet causaal hoeft te zijn aangezien straling en daglengte ook belangrijke factoren zijn;

- Verder zijn er alleen vuistregels beschikbaar op basis van praktijkervaring en het is gewenst om deze te toetsen;

- In 2014 en 2015 startte de grasgroei bij een bodemtemperatuur van circa $8{ }^{\circ} \mathrm{C}$ en dit was circa 4 weken later dan het bereiken van een Tsom 250;250;

- Op natte gronden komt de grasgroei later op gang. Deze bodems warmen langzamer op en het is zodoende aannemelijk om te veronderstellen dat de bodemtemperatuur een belangrijke rol speelt in de start van de groei;

- In februari is de kans op een verschil in ontwikkeling van de Tsom en de bodemtemperatuur het grootst;

- Met het meten van de actuele bodemtemperatuur verbetert waarschijnlijk de voorspelling van de start van de groei in het voorjaar. Misschien niet als vervanger van Tsom, maar mogelijk als extra verklarende parameter;

- Het is mogelijk dat de aanloop naar het bereiken van de gewenste bodemtemperatuur (Tsom bodem) meespeelt in de te verwachten start van de grasgroei;

- De meetdiepte zal invloed hebben op de voorspelling, enerzijds vanwege het dag-nachtritme dat teruggevonden wordt in de meetresultaten en anderzijds vanwege de dikte van de wortelzone, daar waar de interactie met de plant optreedt;

- Het bodemvochtgehalte en de temperatuur van de bodem heeft ook invloed op de mineralisatie van organische stof en de beschikbaarheid van stikstof. Er kan in de voorspelling van de groeistart zodoende een verstrengeling van effecten optreden. 


\section{Aanbevelingen}

De deskstudie heeft niet duidelijk gemaakt of luchttemperatuur of bodemtemperatuur of een combinatie van beide bepalend is voor de start van grasgroei in het voorjaar. Er zijn echter duidelijke aanwijzingen dat bodemtemperatuur hier een belangrijke rol in speelt. Aanbevolen wordt om een veldonderzoek uit te voeren waarin de relatie tussen de bodemtemperatuur, de start van grasgroei en het bemestingstijdstip voor stikstofkunstmest te bepalen. Verwacht wordt dat het bemestingsadvies met het meten van de actuele bodemtemperatuur verbeterd kan worden.

Het doel van het onderzoek zou moeten zijn: vaststellen of met het meten van bodemtemperatuur het bemestingstijdstip voor stikstofkunstmest op gras in het voorjaar beter afgestemd kan worden op de actualiteit voor wat betreft bodem en weer.

Het voorstel is om de proef zodanig in te richten dat het effect van bodemtemperatuur op de groei van de eerste snede bepaald wordt afhankelijk van wel en geen stikstofbemesting, de soort kunstmest en de grondsoort. De proef dient minimaal twee jaar uitgevoerd te worden gezien de sterke weersafhankelijkheid van het verloop van de bodemtemperatuur (neerslag en straling/luchttemperatuur) in het voorjaar. De proef zou in drievoud uitgevoerd moeten worden om de resultaten statistisch betrouwbaar te kunnen toetsen.

Schematisch is de proefopzet als volgt:

Hoofdbehandeling grondsoort:

1. Klei

2. Zand

3. Veen

Subbehandeling type mestgift:

1. Geen bemesting

2. Kunstmest KAS

3. Kunstmest ammonium

Subbehandeling tijdstip bemesting

- Vier tijdstippen die voldoende ver uit elkaar liggen (zie toelichting in het onderstaande).

De waarnemingen in het onderzoek dienen zich enerzijds op de bodem en anderzijds op de grasopbrengst te richten. Daarbij wordt de bodemtemperatuur, het bodemvocht en de buitentemperatuur continue gemeten met sensoren. Aanbevolen wordt om de grasopbrengsten op vijf tijdstippen te bepalen, zodat per behandeling het groeiverloop in de tijd kan worden vastgesteld. Naast de grasopbrengst moet het $\mathrm{N}$-gehalte bepaald worden om de $\mathrm{N}$-benutting te kunnen berekenen. Het $\mathrm{N}$-gehalte is tevens een maat voor het ruw eiwitgehalte (factor 6,25 ) en is een belangrijk kengetal om de eindoogst op te kunnen sturen. De resultaten dienen statistisch getoetst te worden om te zien of de behandelingen significant verschillen.

In het onderstaande worden de behandelingen en waarnemingen nader toegelicht.

\section{Bodemsoort}

Vanwege verschillen in ontwikkeling van bodemtemperatuur bij verschillen in bodemvocht en organische stofgehalte wordt voorgesteld om het onderzoek ten minste uit te voeren op een klei-, zand- en veenbodem. Het zou vanuit bodemtemperatuur ontwikkelingen interessant zijn om binnen een bodemsoort verschillende vochttoestanden mee te nemen. Echter dit zal de proefopzet in dit stadium onnodig uitgebreid maken. 
Type mestgift

Het Tsom onderzoek is uitgevoerd met KAS. Voorgesteld wordt om KAS (snel beschikbare kunstmest) met een ammonium meststof te vergelijken. Ammonium stikstof komt minder snel beschikbaar voor de plant dan nitraat. In het voorjaar worden ammonium meststoffen in de praktijk veel toegepast. De kunstmestgiften worden vergeleken met het niet toedienen van stikstof (nulmeting). Dit geeft inzicht in enerzijds het effect van bemesting en anderzijds in het effect van bodemtemperatuur op grasgroei zonder bemesting. Het is namelijk goed mogelijk dat stikstofgift en bodemtemperatuur een interactieeffect geeft op de start van grasgroei. Ook kan de nulmeting inzicht geven in het effect van bodemtemperatuur op de mineralisatiesnelheid van organische stof in de bodem.

Het voorstel is om het onderzoek eerst op het toedienen van stikstof kunstmest te richten zodat eerst ervaring opgedaan wordt met de toepasbaarheid van de bodemtemperatuur en daarna de proef mogelijk uitgebreid kan worden met drijfmest.

\section{Tijdstip bemesting}

Het voorstel is om vier tijdstippen van bemesting te hanteren. Dit moet nog nader ingevuld worden. Gestreefd wordt om de ontwikkeling van de bodemtemperatuur als uitgangspunt te nemen, maar waarbij ook rekening gehouden wordt met Tsom en weersverwachting. Neerslag en vorst na toediening van kunstmest hebben invloed op de grasopbrengst en de nutriëntenbenutting. In het bepalen van het bemestingsmoment is daarom het voorstel om de 5 en 10-daagse weersvoorspelling mee te nemen. Op basis van de weersverwachting is de ontwikkeling van de bodemtemperatuur te voorspellen. Ook dit kan meegenomen worden in het bepalen van het bemestingstijdstip. Enerzijds is het wenselijk om gebruik te maken van parameters om het optimale bemestingstijdstip vast te stellen en anderzijds dienen de bemestingstijdstippen zodanig ver uit elkaar te liggen, zodat ze een brede range in temperatuur vertegenwoordigen om het effect op opbrengst en stikstofbenutting vast te kunnen stellen. De invulling zal met de CBVG worden besproken evenals de rest van het werkplan.

\section{Meting bodemtemperatuur}

Op basis van de literatuur kon niet geconcludeerd worden op welke diepte gemeten het best gemeten kan worden. Daarom wordt aanbevolen om zowel op $10 \mathrm{~cm}-\mathrm{mv}$ (verwachte traject met meeste wortelbiomassa) als op $20 \mathrm{~cm}$-mv (stabieler verloop bodemtemperatuur) de bodemtemperatuur te meten. Voor het meten wordt gebruikt gemaakt van vaste sensoren waarbij de temperatuur op afstand uit te lezen is. Ter controle wordt een handheld temperatuursensor ingezet.

\section{Luchttemperatuur}

De luchttemperatuur kan betrokken worden van dichtstbijzijnde KNMI weerstations. Op basis hiervan wordt de Tsom berekend.

\section{Worteldiepte}

Uit de literatuur zijn geen aanknopingspunten gevonden op welke diepte de bodemtemperatuur het beste gemeten kan worden. De relatie met worteldiepte kan een rol spelen in de reactie op het effect van bodemtemperatuur op groei. Zodoende is de aanbeveling om de worteldiepte en verdeling van de wortelmassa over de wortelzone te bepalen met een wortelboor.

\section{Oogstmomenten}

Om voor de eerste snede per behandeling een groeicurve te kunnen maken is het voorstel om vijf oogstmomenten te plannen waarop alle veldjes van de voorgestelde behandelingen geoogst worden. Naar verwachting wordt daarmee voldoende het effect van een brede tijdrange in bemestingstijdstippen op de grasopbrengst en $\mathrm{N}$-opname meegenomen.

\section{Herhalingen}

Om voldoende rekening te kunnen houden met variatie binnen het proefveld is de aanbeveling om per locatie de proef in drievoud uit voeren.

Op basis van deze opzet bedraagt het totale aantal proefveldjes 135 per locatie. 


\section{Literatuur}

Agrifirm (2014). http://www.agrifirm.com/agrifirm-

feed/melkvee/nieuws/detail/listitemid/4738\#.VfKc7E3skcM

Baker, A. Young A. (1986), the effect of temperature on the spring growth of perennial ryegrass at three contrasting sites, Grass and Forage Science (1986) Volume 41, 175-178

Barthel M., E. Cieraad, A. Zakharova, J. E. Hunt (2014). Sudden cold temperature delays plant carbon transport and shifts allocation from growth to respiratory demand, Biogeosciences, 11, 14251433,2014

Bussink, D.W. (1999). Verfijning Tsom-advies grasland., Wageningen, Nutriënten Management Instituut NMI BV, Rapportnummer 373.97

Bussink, D.W. (2000). Vernieuwd Tsom advies goed voor grasopbrengst en N-benutting., Wageningen, Nutriënten Management Instituut NMI BV, Praktijkonderzoek Rundvee, Schapen en Paarden (PR), 13 (2000)1. - ISSN 1386-8470 - p. 26 - 28.

Bussink, D.W. (2006). Re-gras, Bedrijfsspecifiek advies voor het sturen op ruweiwit, grasopbrengst en stikstofbenutting., Wageningen, Nutriënten Management Instituut NMI BV

Bussink, D.W. (2016). (update originele versie 2006) REgras. Bedrijfsspecifiek advies voor het sturen op ruweiwit, grasopbrengst en stikstofbenutting. Wageningen, Nutriënten Management Instituut NMI BV.

Commissie Bemesting Grasland en Voedergewassen (2012). Bemestingsadvies. Lelystad, Wageningen UR Livestock Research. www.bemestingsadvies.nl

Deru J., N. Eekeren, H. Boer (2010). Beworteling van grasland - een literatuurstudie. Publicatienummer 2010-018 LbV.

Ennik, G. C. (1981). Grasgroei en beworteling, Wageningen, NL: C.A.B.O. verslag nr 38

Frame, J. and A.S. Laidlow (1992). Improved grassland management. Framning Press, Ipswich, p. 351.

De Gooijer, H and J.D. Jagtenberg (1968). De temperatuursom als criterium voor de datum van stikstof strooien op grasland in het voorjaar.

Jacobs A.F.G., B. G. Heusinkveld, A. A.M. Holtslag (2011). Long-term record and analysis of soil temperatures and soil heat fluxes in a grassland area, The Netherlands., Agricultural and Forest Meteorology 151 (2011) 774-780

Lambert R., A. Peeters, B. Toussaint (1999), LAI evolution of a perennial ryegrass crop estimated from the sum of temperatures in spring time, Agricultural and Forest Meteorology 97 (1999) $1 \pm 8$

Locher W.P. en H.de Bakker (1990). Bodemkunde van Nederland, deel 1, Algemene bodemkunde, Hoofdstuk 13, warmtehuishouding

Remmelink G., Philipsen, B., Stienezen, M., Tjoonk, L., Kuiper, I. (2015). "Eerste curve grasgroei en bodemtemperatuur : extra grasland special \V-focus : vakblad voor adviseurs in de dierlijke sector." P 24- 25 
Ros, G.H., L. van Schöll, D.W. Bussink. (2010) N-advies op nieuwe leest, Wageningen, Nutriënten Management Instituut NMI BV, rapport 1248.N.07

Schothorst, C.J. (1980), De voorjaarsproductie en het effect van ontwatering in diverse weidegebieden.

Stienezen, M.W.J., G.J. Remmelink, T. Van Der Weiden, L. Tjoonk, J.E. Nolles, W. Voskamp-Harkema and A. Van Den Pol-Van Dasselaar (2016). Netherlands grass monitoring network, Grassland Science in Europe, Volume 21, pages 74-76.

Thomas H. and I. B. Norris (1977) The growth response of Lolium Perenne to the weather during winter and spring at various altitudes in Mid-Wales. J. apple. Ecol. (1977), 14,-949-964

Verloop K. (2013). Limits of effective nutrient management in dairy farming, PhD thesis, Wageningen University, Wageningen, NL (2013), ISBN 978-94-6173-719-9

Visscher, J. (2010). Verlenging groeiseizoen grasland, Lelystad, NL: Wageningen UR Livestock Research.

Whitehead, D.C. (2000). NUTRIENT ELEMENTS IN GRASSLAND Soil-Plant-Animal Relationships. Department of soil science University of Reading. 


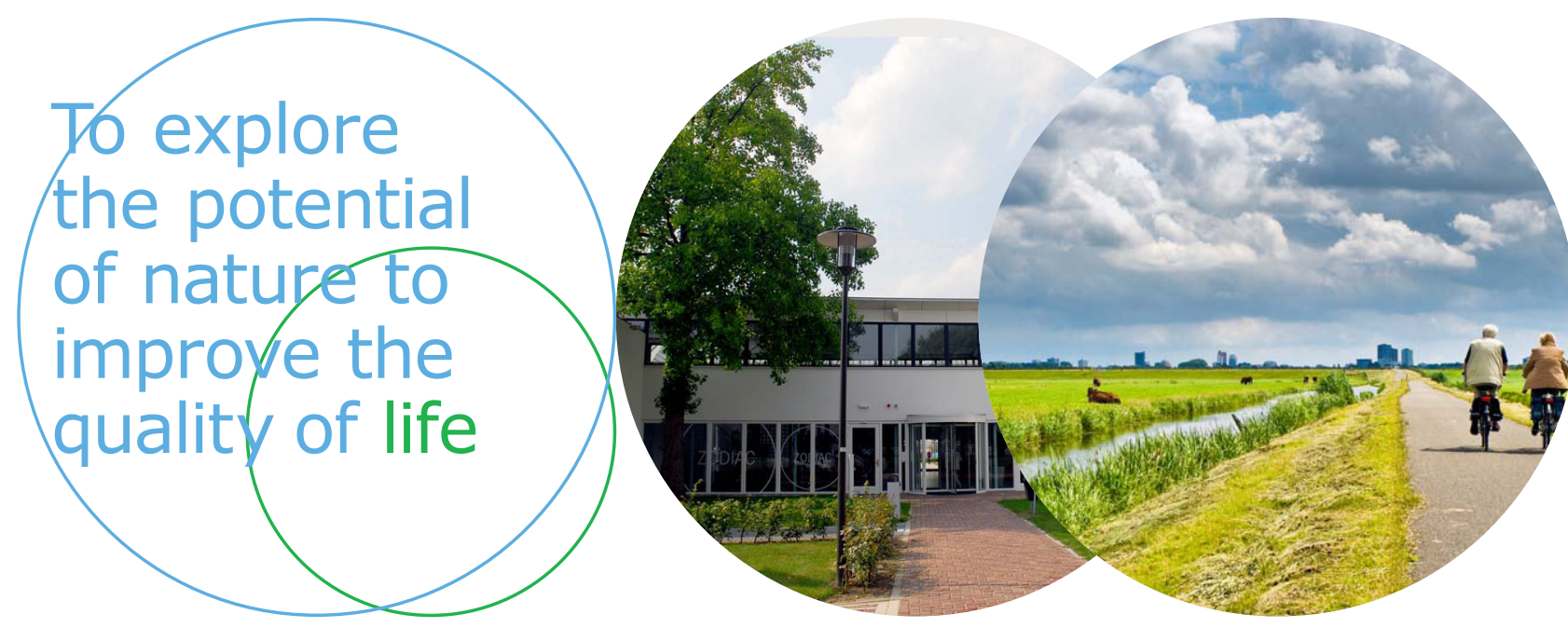

Wageningen Livestock Research Postbus 338

$6700 \mathrm{AH}$ Wageningen

T 0317483953

E info.livestockresearch@wur.nl www.wur.nl/livestock-research
Wageningen Livestock Research ontwikkelt kennis voor een zorgvuldige en renderende veehouderij, vertaalt deze naar praktijkgerichte oplossingen en innovaties, en zorgt voor doorstroming van deze kennis. Onze wetenschappelijke kennis op het gebied van veehouderijsystemen en van voeding, genetica, welzijn en milieu-impact van landbouwhuisdieren integreren we, samen met onze klanten, tot veehouderijconcepten voor de $21 \mathrm{e}$ eeuw.

De missie van Wageningen University \& Research is 'To explore the potential of nature to improve the quality of life'. Binnen Wageningen UR bundelen 9 gespecialiseerde onderzoeksinstituten van stichting DLO en Wageningen University hun krachten om bij te dragen aan de oplossing van belangrijke vragen in het domein van gezonde voeding en leefomgeving. Met ongeveer 30 vestigingen, 6.000 medewerkers en 10.000 studenten behoort Wageningen UR wereldwijd tot de aansprekende kennisinstellingen binnen haar domein. De integrale benadering van de vraagstukken en de samenwerking tussen verschillende disciplines vormen het hart van de unieke Wageningen aanpak. 